\title{
APRICOT PIP SHELLS USED AS AGGREGATE REPLACEMENT
}

\author{
Servet Yildiz ${ }^{1}$, Mehmet Emiroğlu' ${ }^{2}$ Onur Atalar ${ }^{3}$ \\ ${ }^{1,3}$ Firat University Technical Education Faculty, Department of Construction Education, 23200 Elazig, Turkey \\ ${ }^{2}$ Düzce University Technical Education Faculty, Department of Construction Education, 81620 Düzce, Turkey

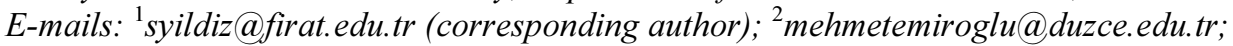 \\ 3onur_atalar@hotmail.com \\ Received 18 Sept. 2009; accepted 03 Mar. 2011
}

\begin{abstract}
To improve the undesired characteristics of concrete, for example high $\mathrm{CO}_{2}$ emission and loss of strata from quarrying of raw materials, environmentally hazardous solid waste could be utilized as cement, sand and/or aggregate replacement. Apricot Pip Shells (APSs) are an environmental problem mainly in the region where apricots are cultivated. The shells are burnt as a fuel by local people in this region. An alternative use for this waste material would be for aggregate replacement in concrete as reported in this paper. In this study, limestone aggregate were substituted by different percentage of APS in the prepared concrete mixes. Unit weight, compressive and tensile strength tests were conducted on the specimens. A decrease was observed in the strength development of the concrete containing APS. This may have resulted from the weak adherence between APSs and cement paste in the interfacial transition zone. However, the unit weight of the concrete decreased for higher APS content in the mix.
\end{abstract}

Keywords: solid wastes, waste recovery, artificial aggregate, concrete, strength reduction factor.

\section{Introduction}

Since increase in cost of the raw materials and the decrease in the natural resources, use of the waste materials in concrete is an effective resource for the construction industry. Some of the waste materials such as fly ash, grand granulated furnace slag, recycled-crushed glass and shredded tire aggregates are commonly used as substitutes of natural aggregates or cement in concrete industry (Mannan, Ganapathy 2004; Siddique, Naik 2004).

There are various studies concerning the use of waste materials in the concrete. To obtain more ductile concretes waste tire chips instead of limestone aggregate has been reported in the literature for the last two decades (Topçu 1997; Khatib, Bayomy 1999; Güneyisi et al. 2004; Emiroğlu et al. 2008). Determination of mechanical characteristics of concretes containing glass aggregate has also been studied in recent years (Wu et al. 1996; Shao et al. 2000; Park et al. 2004; Topçu, Canbaz 2004). Industrial waste materials, for example ground granulated blast furnace slag, rice husk ashes, various particle size of wood shavings, recycled concrete aggregates, recycled fibers etc. are used as waste materials in civil engineering (Malhotra 1993; Ozyildirim 1994; Yıldız et al. 2006; Koçak 2010; Subaşı et al. 2010).

Agricultural and industrial wastes are stockpiled in developing countries. Material recovery from the conversion of agricultural or industrial wastes into useful materials has environmental gains such as minimizing the extraction of natural resources and maximizing the useful life of the sanitary land-fillings etc. For the purpose of preparing concrete to provide different requirements such as making building construction as floors, slabs, particle boards, panels etc. some of the agricultural wastes have been used by totally or partially replacing with the aggregate in concrete (Mannan, Ganapathy 2004; Rodrigues et al. 2004; Yıldız et al. 2007; İşbilir et al. 2010).

Apricot pip shells (APS) which are the seed of apricot fruits caused environmental problems in around their cultivated regions. These shells have accumulated throughout the apricots growth areas and a small amount of these shells are generally used as fuel by the region's people.

The production of concrete incorporating waste materials as aggregate replacement has become very popular nowadays. APSs can be used to replace limestone aggregates in cementititous material due to its hard and cellular structure. In this study, a number of laboratory tests have been carried out on concrete specimens using APSs as aggregate replacement. Limestone aggregate is substituted with the different replacement levels $(0 \%, 5 \%, 10 \%$, $15 \%, 20 \%, 25 \%, 30 \%, 35 \%$ and $40 \%$ ) of APS aggregate in the prepared concrete mixes.

\section{Experimental procedure}

The materials used to develop the concrete mixes in this experimental study were fine $(0-4 \mathrm{~mm})$ and coarse $(4-$ $8 \mathrm{~mm}$ ) limestone aggregates, apricot pip shells and cement. Limestone aggregate were obtained from Palu River. Type I Portland cement was used in all mix designs. APSs used in this study were obtained after the sulphurizing process in apricot drying factories. These shells were washed to clean their sulphurized surfaces before using 


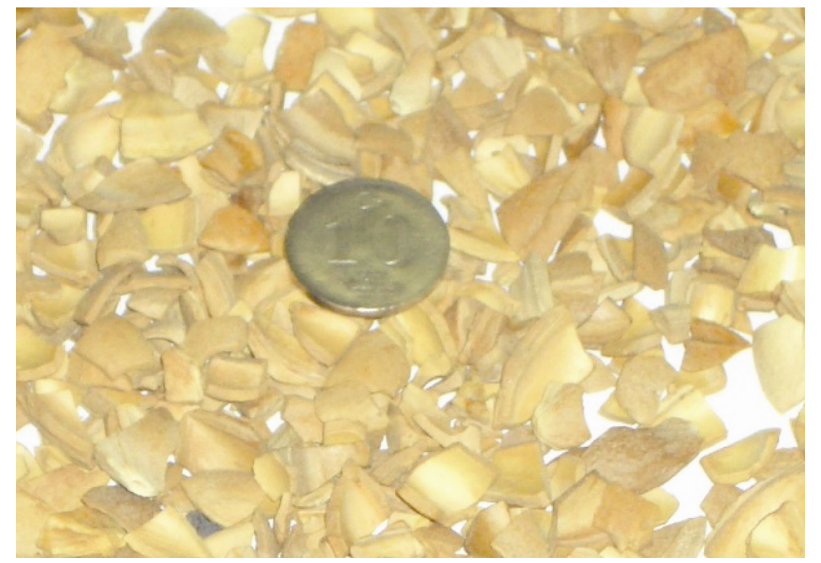

Fig. 1. Apricot pip shells

them as aggregate in concrete (Fig. 1). Specific gravity of limestone and the APS aggregates are 2.56 and 1.30, respectively.

A plain concrete mix was designed with a $30 \mathrm{MPa}$ in accordance to TS 802 (1980) Standards. The other concrete mixes had limestone aggregate substituted at various replacement levels $(5 \%, 10 \%, 15 \%, 20 \%, 25 \%$, $30 \%, 35 \%$ and $40 \%$ ) by APSs. All mix design parameters were kept constant except for the aggregate component. The mix ratio for the plain concrete was cement/water/ gravel $/$ sand $=1 / 0.55 / 1.28 / 2.38$ by weight; and the APS and limestone aggregate quantities for the other concrete mixes are summarized in Table 1. For each mix, three cubes of $100 \times 100 \times 100 \mathrm{~mm}$ and three standard beams of $100 \times 100 \times 500 \mathrm{~mm}$ were prepared. The specimens were de-moulded after 24 hours and cured in water for 28 days. After the curing period unit weight, compressive strength and three point bending strength tests were conducted on the specimens in accordance with TS EN 12390-7 (2002), TS EN 12390-3 (2003) and TS EN 12390-5 (2003) Standards respectively.

\section{Results and discussion}

\subsection{Effect on unit weight}

The unit weight of the concrete ranged from 2220 to $1840 \mathrm{~kg} / \mathrm{m}^{3}$, depending on the APS content. The unit weight of the concrete containing APS was gradually decreased compared to plain concrete (Table 2). The

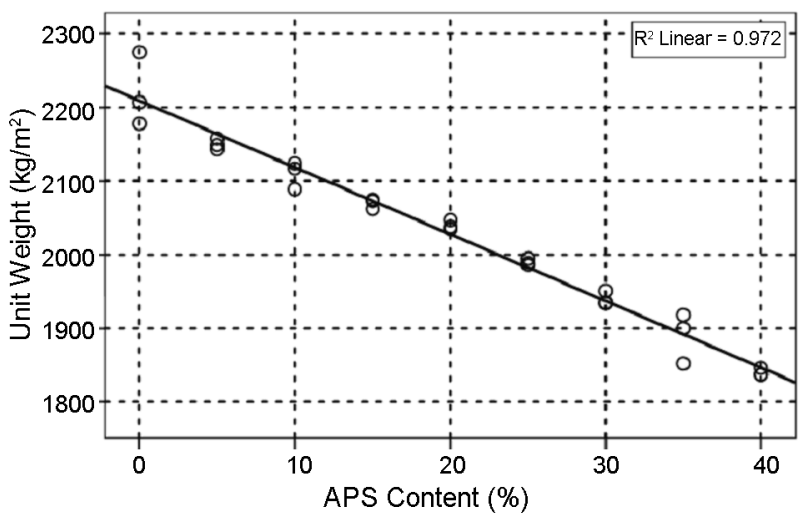

Fig. 2. Relationship between unit weight and APS content

reduction in unit weight is a result of the lower unit weight of APS replacing the normal aggregates. The unit weight of the specimens is reported in Fig. 2.

\subsection{Effect on strength}

The results reflected a systematic reduction in the concrete compressive and tensile strength with the increase of APS content in the concrete (Table 2).

Table 2. Experimental results of concrete including APS

\begin{tabular}{c|c|c|c}
\hline $\begin{array}{c}\text { APS } \\
\text { Content } \\
(\%)\end{array}$ & $\begin{array}{c}\text { Compressive } \\
\text { Strength } \\
(\mathrm{MPa})\end{array}$ & $\begin{array}{c}\text { Unit } \\
\text { Weight } \\
\left(\mathrm{kg} / \mathrm{m}^{3}\right)\end{array}$ & $\begin{array}{c}\text { Tensile } \\
\text { Strength } \\
(\mathrm{MPa})\end{array}$ \\
\hline 0 & 34.65 & 2220 & 4.17 \\
\hline 5 & 32.05 & 2150 & 4.15 \\
\hline 10 & 28.21 & 2110 & 4.13 \\
\hline 15 & 26.18 & 2070 & 4.06 \\
\hline 20 & 22.85 & 2040 & 3.99 \\
\hline 25 & 20.46 & 1990 & 3.92 \\
\hline 30 & 18.93 & 1940 & 3.88 \\
\hline 35 & 17.20 & 1890 & 3.86 \\
\hline 40 & 14.92 & 1840 & 3.43 \\
\hline
\end{tabular}

Concrete is heterogeneous and the aggregate particles are not only having irregularly shaped but also imperfectly bonded to the cement. Thus, highly localized stress and strain may be quite different from the nominal applied stress and strain. The localized strain may be as much as 4.5 times the average strain, and localized stress

Table 1. APS and limestone aggregate quantities for $1 \mathrm{~m}^{3}$ mix design

\begin{tabular}{c|c|c|c|c|c|c|c|c}
\hline \multirow{2}{*}{$\begin{array}{c}\text { APS Content } \\
(\%)\end{array}$} & \multicolumn{2}{|c|}{$\begin{array}{c}\text { Fine APS } \\
(0-4 \mathrm{~mm})\end{array}$} & \multicolumn{2}{c|}{$\begin{array}{c}\text { Coarse APS } \\
(4-8 \mathrm{~mm})\end{array}$} & \multicolumn{2}{c|}{$\begin{array}{c}\text { Fine Aggregate } \\
(0-4 \mathrm{~mm})\end{array}$} & \multicolumn{2}{c}{$\begin{array}{c}\text { Coarse Aggregate } \\
(4-8 \mathrm{~mm})\end{array}$} \\
\cline { 2 - 9 } & $\begin{array}{c}\text { Volume } \\
\left(\mathrm{dm}^{3}\right)\end{array}$ & $\begin{array}{c}\text { Weight } \\
(\mathrm{kg})\end{array}$ & $\begin{array}{c}\text { Volume } \\
\left(\mathrm{dm}^{3}\right)\end{array}$ & $\begin{array}{c}\text { Weight } \\
(\mathrm{kg})\end{array}$ & $\begin{array}{c}\text { Volume } \\
\left(\mathrm{dm}^{3}\right)\end{array}$ & $\begin{array}{c}\text { Weight } \\
(\mathrm{kg})\end{array}$ & $\begin{array}{c}\text { Volume } \\
\left(\mathrm{dm}^{3}\right)\end{array}$ & $\begin{array}{c}\text { Weight } \\
(\mathrm{kg})\end{array}$ \\
\hline 5 & 19.40 & 25.22 & 10.45 & 13.59 & 368.60 & 943.62 & 198.55 & 508.29 \\
\hline 10 & 38.80 & 50.44 & 20.90 & 27.17 & 349.20 & 893.95 & 188.10 & 481.54 \\
\hline 15 & 58.20 & 75.56 & 31.35 & 40.76 & 329.80 & 844.29 & 177.65 & 454.78 \\
\hline 20 & 77.60 & 100.88 & 41.80 & 54.34 & 310.40 & 794.62 & 167.20 & 428.03 \\
\hline 25 & 97.00 & 126.10 & 52.25 & 67.93 & 291.00 & 744.96 & 156.75 & 401.28 \\
\hline 30 & 116.40 & 151.32 & 62.70 & 81.51 & 271.60 & 695.30 & 146.30 & 374.53 \\
\hline 35 & 135.80 & 176.54 & 73.15 & 95.10 & 252.20 & 645.63 & 135.85 & 347.78 \\
\hline 40 & 155.20 & 201.76 & 83.60 & 108.68 & 232.80 & 595.97 & 125.40 & 321.02 \\
\hline
\end{tabular}




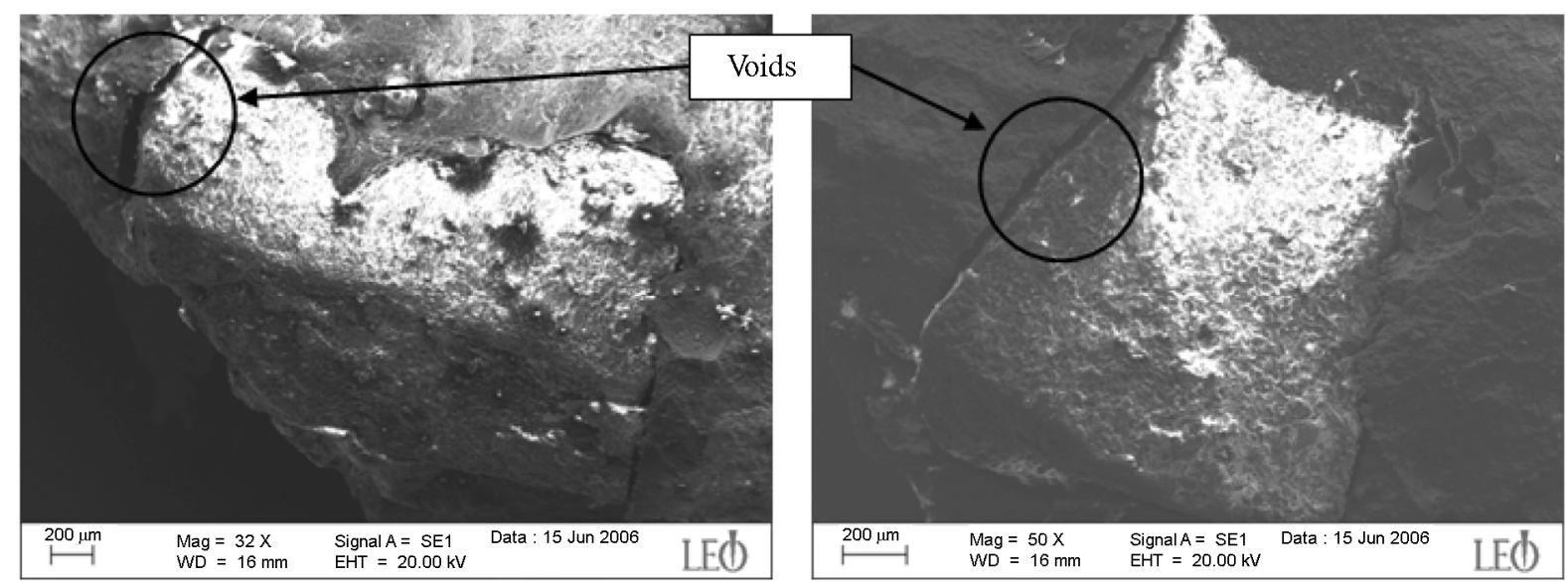

Fig. 3. SEM image of the concrete including APS

may be more than twice as high as the average stress (Mindess, Young 1981). For this reason it is considered that initial cracking occurs at the interface between the paste and APS.

Because of the softening and deformable structure of the APS and the lack of the adherence between APSs and the cement paste, on loading, initial crack formations may be started around the APSs in the mix and the failure has accelerated. It is clear from the Scanning Electron Microscopy (SEM) photograph that the weak adherence resulted from the presence of the voids into the concrete including APS (Fig. 3).

The ratio of tensile strength to compressive strength $\left(f_{l} / f_{c}\right.$, experimental) based on the experimental data is found to be similar to the ratio of the two strengths $\left(f_{t} / f_{c}\right.$, theoretical) computed. The theoretical tensile strength of the concrete was calculated from the Eq. (1), derived by Raphael (1984) and ACI Committee 318M-05 (2005):

$$
f_{t}=0.3\left(f_{c}\right)^{2 / 3} \text {. }
$$

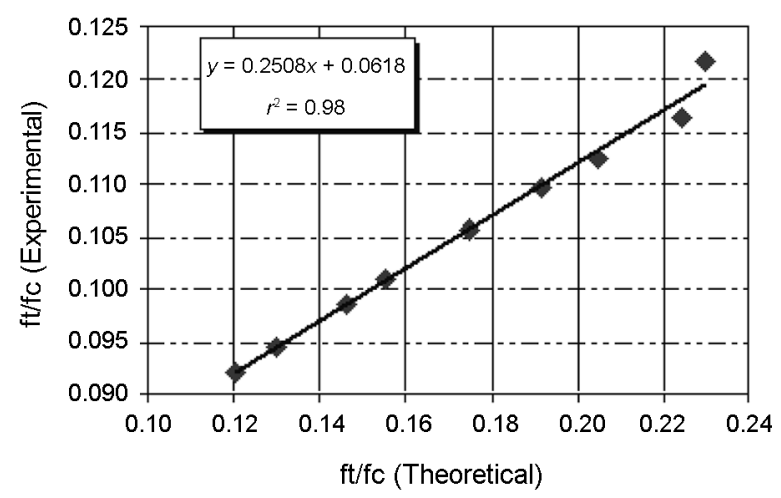

Fig. 4. Relationship between experimental and theoretical results

Fig. 4 shows the $\left(f_{t} / f_{c}\right.$ Theoretical $)$ versus $\left(f_{t} / f_{c}\right.$ Experimental). Eq. (1) gives the best fitting $\left(r^{2}=0.988\right)$ the overall results of the study. Based on the experimental evidence, including the compressive strength in the empirical formulas is very effective way for the prediction of the concrete tensile strength as reported the literature (Arioglu et al. 2006; Batayneh et al. 2008).

\subsection{Strength Reduction Factor (SRF)}

To determine the strength reduction of the concrete based on the APS content in the mixture, a test was made to simulate the strength reduction by a characteristic function and the parameters of this function were determined through the nonlinear regression analysis. The SRF was defined as the ratio of the strength (compressive or tensile strengths) of the mixture containing APS in the rate of $(R)$ to that of the control mixture. The APS content $R$ is a volumetric ratio by the total aggregate volume. At $0 \%$ APS (control mix), $S R F$ must equal one. Thus, the $S R F$ characteristic function must be a decreasing curvilinear function with a starting value of one at zero APS content. Close analysis of the data revealed that such a function needs to be asymptotic to horizontal at high APS content. The utilized characteristic function which is used by Khatib and Bayomy (1999) and Güneyisi et al. (2004) was listed in the Eq. (2):

$$
S R F=a+b(1-R)^{m},
$$

with the condition that:

$$
a+b=1,
$$

where: $S R F$ - strength reduction factor; $R$ - APS content, volumetric ratio by total aggregate volume; and $a, b$, and $m$ - function parameters.

The relevant function parameters $(a, b$, and $m)$, and Pearson correlation coefficients $\left(r^{2}\right)$ are summarized in Table 3. The test data obtained for compressive and tensile strengths were applied to Eq. (1) through regression analysis and presented in Fig. 5.

The regression analyses indicate that the function parameters strongly depend on the concrete compressive and tensile strength test results.

Table 3. Parameters of the proposed models for concrete properties and statistical test results

\begin{tabular}{c|c|c}
\hline \multirow{2}{*}{$\begin{array}{c}\text { Model } \\
\text { Parameters }\end{array}$} & \multicolumn{2}{|c}{ Strength Type } \\
\cline { 2 - 3 } & Compressive Strength & Tensile Strength \\
\hline $\mathrm{a}$ & 0.360 & 0.876 \\
\hline $\mathrm{b}$ & 0.640 & 0.124 \\
\hline $\mathrm{m}$ & 3.540 & 2.125 \\
\hline $\mathrm{r}^{2}$ & 0.988 & 0.945 \\
\hline
\end{tabular}



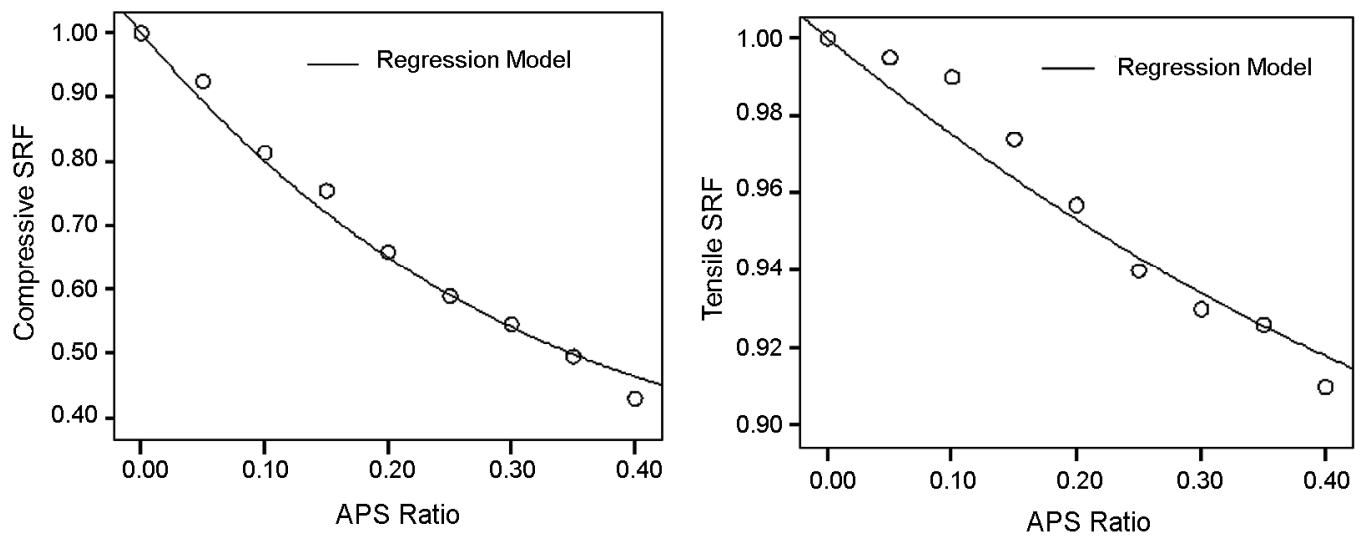

Fig. 5. Relationship of compressive and tensile SRF and APS content

\section{Conclusions}

The test results indicate that it is possible to utilize of APS in concrete mixtures. Based on these results, the following can be concluded:

- Mixing, casting and compacting the concrete mix using APS with local materials can be carried out in a similar fashion to that of the conventional concrete mix;

- Based on the experimental results, the concrete including APS resulted in lighter weight concrete. Unit weights of the concrete including 5\%, $10 \%$, $15 \%, 20 \%, 25 \%, 30 \%, 35 \%$ and $40 \%$ of APS was decreased $3.15 \%, 4.95 \%, 6.76 \%, 8.11 \%, 10.36 \%$, $12.61 \%, 14.86 \%$ and $17.12 \%$, respectively;

- The test results indicated that there was a systematic reduction in the compressive and tensile strengths. Although it is not recommended to use concrete that contains aggregates replaced with APSs in structural elements where high strength is required, it can be used in many other construction elements like partition walls, road barriers, pavement, sidewalks, etc. which are in high demand in the construction industry;

- A mathematical function is used which estimates the reduction in the strength for the concrete including APS based on the APS content by the total aggregate volume. This function is helpful in establishing the targeted strength for mix design purposes. Analysis of the function parameters revealed that the function exponent $m$ is an indicator of the mix sensitivity to loss of strength based on the APS content.

As a result of the experimental study, the lightweight concrete which has $2000 \mathrm{~kg} / \mathrm{m}^{3}$ unit weight can be produced using APS as supplement up to the $25 \%$ in the mixture.

Having considered all the findings of this experimental study, the study will contribute to the management of APS by offering an outlet for this waste material by using the shells as aggregate replacement in concrete to be used in applications that require low to medium strength concrete.

\section{References}

ACI Committee 318: Building Code Requirements for Reinforced Concrete. American Concrete Institute, Detroit, Michigan, 1995. $430 \mathrm{p}$.

Arioglu, N.; Girgin, Z. C.; Arioglu, E. 2006. Evaluation of ratio between splitting tensile strength and compressive strength for concretes up to $120 \mathrm{MPa}$ and its application in strength criterion, ACI Materials Journal 103(1): 18-24.

Batayneh, M. K.; Marie, I.; Asi, I. 2008. Promoting the use of crumb rubber concrete in developing countries, Waste Management 28(11): 2171-2176.

http://dx.doi.org/10.1016/j.wasman.2007.09.035

Emiroğlu, M.; Yıldız, S.; Keleştemur, M. H. 2008. An investigation on ITZ microstructures of the concrete containing waste vehicle tire, Computers and Concrete 5(5): 503-508.

Güneyisi, E.; Gesoğlu, M.; Özturan, T. 2004. Properties of rubberized concretes containing silica fume, Cement and Concrete Research 34(12): 2309-2317. http://dx.doi.org/10.1016/j.cemconres.2004.04.005

İşbilir, B.; Subaş1, S.; Ercan, İ. 2010. Effect of rice husk ash on concrete durability, in International Sustainable Buildings Symposium (ISBS), 26-28 May, 2010, Ankara, Turkey, 76-81.

Khatib, Z. K.; Bayomy, F. M. 1999. Rubberized Portland cement concrete, Journal of Materials in Civil Engineering ASCE 11(3): 206-213. http://dx.doi.org/10.1061/(ASCE) 0899-1561(1999)11:3(206)

Koçak, Y. 2010. A Study on the effect of fly ash and silica fume substituted cement paste and mortars, Scientific Research and Essays 5(9): 990-998.

Malhotra, V. M. 1993. Fly ash, slag, silica fume, and rice husk ash in concrete: A review, Concrete International ACI 15(4): 23-28.

Mannan, M. A.; Ganapathy, C. 2004. Concrete from an agriculture waste-oil palm shell (OPS), Building and Environment 39(4): 441-448. http://dx.doi.org/10.1016/j.buildenv.2003.10.007

Mindess, S.; Young, J. F. 1981. Concrete. Englewood Cliffs, New Jersey: Prentice-Hall, Inc. 671 p.

Ozyildirim, C. 1994. Laboratory investigation of lowpermeability concretes containing slag and silica fume, ACI Materials Journal 91(2): 197-202.

Park, S. B.; Lee, B. C.; Kim, J. H. 2004. Studies on mechanical properties of concrete containing waste glass aggregate, Cement and Concrete Research 34(12): 2181-2189. http://dx.doi.org/10.1016/j.cemconres.2004.02.006 
Raphael, J. M. 1984. Tensile Strength of Concrete, ACI Journal 81(2): 158-165.

Rodrigues, J. M. R. P.; Ferreira, O. P.; Claro, N. S. 2004. Utilization of scrap tires in the production of building materials to civil construction, in International RILEM Conference on the Use of Recycled Materials in Buildings and Structures, 8-11 November, 2004, Barcelona, Spain, 472479.

Shao, Y.; Lefort, T.; Moras, S.; Rodriguez, D. 2000. Studies on concrete containing ground waste glass, Cement and Concrete Research 30(1): 91-100. http://dx.doi.org/10.1016/S0008-8846(99)00213-6

Siddique, R.; Naik, T. R. 2004. Properties of concrete containing scrap-tire rubber - an overview, Waste Management 24(6): 563-569. http://dx.doi.org/10.1016/j.wasman.2004.01.006

Subaşı, S.; Koçak, Y.; Emiroğlu, M. 2010. The effect of fly ash type and quantity on mechanical properties of cement, in International Sustainable Buildings Symposium (ISBS), 24-28 May, 2010, Ankara, Turkey, 86-90.

Topçu, İ. B.; Canbaz, M. 2004. Properties of concrete containing waste glass, Cement and Concrete Research 34(2): 267274. http://dx.doi.org/10.1016/j.cemconres.2003.07.003

Topçu, İ. B. 1997. Assessment of the brittleness index of rubberized concretes, Cement and Concrete Research 27(2): 177-183.

http://dx.doi.org/10.1016/S0008-8846(96) 00199-8
TS 802 Design Concrete Mixes. Turkish Standards Institution, Ankara, 1980.

TS EN 12390-3 Testing hardened concrete - Part 3: Compressive strength of test specimens. Turkish Standards Institution, Ankara, 2003.

TS EN 12390-5 Testing hardened concrete - Part 5: Flexural strength of test specimens. Turkish Standards Institution, Ankara, 2003.

TS EN 12390-7 Testing hardened concrete - Part 7: Density of hardened concrete. Turkish Standards Institution, Ankara, 2002.

Wu, H. C.; Lim, Y. M.; Li, V. C.; Foremsky, D. J. 1996. Utilization of recycled fibers in concrete, in Proc. of The ASCE 4th Materials Engineering Conference, Washington, D.C., November, 1996, 799-808.

Yıldız, S.; Yalınbaş, M.; Kelestemur, O. 2006. Silis dumanı katkılı yapı alçılarında basınç dayanımının araştırılması [Investigation of compressive strength of silica fume in building plasters], Uludă̆ Üniv. Müh.-Mim. Fak. Dergisi 11(2): 15-21.

Yıldız, S.; Balaydın, I.; Ulucan, Z. 2007. Pirinç kabuğu külünün beton dayanımına etkisi [The effect of rice husk ash concrete strength], Science and Engineering Journal of Firat University 19(1): 85-91.

Servet YILDIZ. An Associate Professor at the Department of Construction Education, Firat University, Elazig, Turkey. His main research interests include building materials and concrete technology, cement, puzzolans.

Mehmet EMIROĞLU. A lecturer at the Department of Construction Education, Duzce University, Duzce, Turkey. He has Master of Science in Construction Education from Technical Education Faculty at Firat University, Elazig, Turkey. His interests include alternative aggregates, cementitious materials, industrial wastes and concrete technology.

Onur ATALAR. Master of Science in Construction Education from Technical Education Faculty at Firat University, Elazig, Turkey. 